\title{
Zoo-sanitary aspects of goat husbandry in Southeastern Brazil
}

\section{Aspectos zoossanitários da caprinocultura no Sudeste do Brasil}

\author{
Aurora Maria Guimarães Gouveia ${ }^{1}$; Marcos Xavier Silva ${ }^{1}$; \\ Gabriela Canabrava Gouveia²; Humberto Mello Brandão ${ }^{3}$; \\ Letícia Caldas Mendonça4; Alessandro de Sá Guimarães ${ }^{5 *}$
}

\begin{abstract}
Minas Gerais is the largest one out of the four states that comprise the southeastern region of Brazil, with the bigest goat herd of this region. The characterization of health aspects of dairy goat husbandry was done in 84 dairy herds in 81 municipalities and 200 beef herds in 70 municipalities in the State of Minas Gerais. A questionnaire was filled out for each herd, requesting data regarding the farm, the herd and the farmer by the veterinarians within the Agriculture and Livestock Institute of Minas Gerais (Instituto Mineiro de Agropecuária - IMA). A data bank was developed in Windows Excel and analyzed using the Epi-Info system. Comparisons of categorical variables were based on Chi-square test. The individual identification of the animals was done at $73.8 \%$ of dairy farms and at $7.5 \%$ of beef farms, use of quarentine at $15.5 \%$ and $4.0 \%$, isolation of sick animals at $30.9 \%$ and $11.0 \%$, requisition of sanitary certificate in the acquisition of new animals at $28.6 \%$ and $1.5 \%$, regular veterinary monitoring at $52.4 \%$ and $1.5 \%$, respectively. The main health problems reported at dairy and beef farms, respectively, were abortion $(50.0 \%$ and $49.5 \%)$, mastitis $(41.7 \%$ and $19.0 \%)$, pneumonia $(37.4 \%$ and $16.5 \%)$, diarrhea $(34.5 \%$ and $16.5 \%)$ and caseous lymphadenitis $(20.2 \%$ and $43.0 \%)$.
\end{abstract}

Key words: Goat husbandry, epidemiological and health aspects, Minas Gerais, Brazil

\section{Resumo}

Minas Gerais é o mais extenso dos quatro estados que compõem a região sudeste do Brasil, com o maior efetivo caprino dessa região. A caracterização dos aspectos sanitários da caprinocultura foi realizada em 84 rebanhos leiteiros em 81 municípios e 200 rebanhos de carne em 70 municípios de Minas Gerais. Um questionário foi preenchido para cada rebanho, requisitando informações sobre a fazenda, o rebanho e proprietario, realizado por veterinários do Instituto Mineiro de Agropecuaria (IMA). Um banco de dados foi desenvolvido em Windows Excel e analisado utilizando o programa Epi-Info. Comparaçãoes entre variáveis categoricas foram feitas com teste de Qui-quadrado. A identificação individual dos animais era realizada em $73,8 \%$ das propriedades leiteiras e em 7,5\% das propriedades de corte, o uso da quarentena em $15,5 \%$ e 4,0\%, o isolamento de animais doentes em 30,9\% e 11,0\%, a solicitação de certificados

1 Profs. de Medicina Veterinária, Escola de Veterinária, Universidade Federal de Minas Gerais, UFMG, Belo Horizonte, MG, Brasil. E-mail: auroragouveia@terra.com.br; marcosxavier@ufmg.br

2 Discente de Medicina Veterinária, Escola de Veterinária, Universidade Federal de Minas Gerais, UFMG, Belo Horizonte, MG, Brasil. E-mail: gabigouveia@vet.grad.ufmg.br

3 Pesquisador, Núcleo de Sanidade Animal/Qualidade do Leite/Nanotecnologia, Embrapa Gado de Leite, Juiz de Fora, MG, e Prof. do Programa de Pós-Graduação em Farmácia, Universidade Federal de Ouro Preto, UFOP, Ouro Preto, MG, Brasil. E-mail: humberto.brandao@embrapa.br

4 Analista Núcleo de Sanidade Animal/Qualidade do Leite/Nanotecnologia, Embrapa Gado de Leite, Juiz de Fora, MG, Brasil. E-mail: letícia.mendonca@embrapa.br

5 Pesquisador, Núcleo de Sanidade Animal/Qualidade do Leite/Nanotecnologia, Embrapa Gado de Leite, Juiz de Fora, MG, e Prof. do Programa de Pós-Graduação em Medicina Veterinária, Universidade Federal de Lavras, UFLA, Lavras, MG, Brasil. E-mail: alessandro.guimaraes@embrapa.br

* Autor para correspondência 
sanitarios na aquisição de novos animais em $28,6 \%$ e 1,5\%, o monitoramento veterinário em $52,4 \%$ e $1,5 \%$, respectivamente. Os principais problemas sanitários relatados, nas propriedades leiteiras e de carne foram, respectivamente, aborto $(50,0 \%$ e $49,5 \%)$, mastite $(41,7 \%$ e $19,0 \%)$, pneumonia $(37,4 \%$ e $16,5 \%)$, diarreia $(34,5 \%$ e $16,5 \%$ ) e a linfadenite caseosa $(20,2 \%$ e $43,0 \%)$.

Palavras-chave: Caprinocultura, aspectos epidemiológicos e sanitários, Minas Gerais, Brasil

\section{Introduction}

Dairy goat husbandry is relatively recent in Brazil, compared to countries where such farming is highly explored. In 1978, the State of Minas Gerais (MG) was a pioneer in the development of goat husbandry, mainly dairy production with specialized goat breeds imported from different European countries, the United States and Canada, aiming to improve the genetic potential and milk production of herds. These imports have induced changes in the goat production systems in the southeastern region of Brazil. Moreover, the absence of specific health legislation for the species has allowed the spread of important diseases throughout the country, resulting in losses regarding livestock productivity as well as in the quality of dairy products. The commercial beef goat rearing began in 2001 with import the boer breed animals in MG (FONSECA; BRUSCHI, 2009). After this period, the goat population remained constant, but higher than the year in which imports were closed, showing growth efforts by farmers.

There are few epidemiological studies with goat farms in Brazil and worldwide. Zoo-sanitary management of goat herds has been studied in Northeastern Brazil, in the States Bahia (TINÔCO, 1983), Pernambuco (SOUZA NETO et al., 1996), Paraíba and Rio Grande do Norte (SOUZA NETO; GUTIERREZ, 1987) and Ceará (PINHEIRO et al., 2000). The high mortality found in properties in the Northeast, reported is the main cause of the low productivity rates at the farms in that region. These indexes come from management failures, especially regarding health, mostly due to lack of hygiene at the facilities and inappropriate use of anthelmintics and vaccines (CALDAS, 1989; SOUZA NETO et al., 1996).
The only survey which has characterized the use of dairy farming practices in goat husbandry was performed by the same group (MAGALHÃES et al., 1985) in the region of Zona da Mata in the States of Minas Gerais and Rio de Janeiro, southeastern region. This study aimed to assess, in detail, the epidemiological and health problems existing at the goat farms in State of Minas Gerais, thereby guiding breeders, technicians and researchers in the development of the goat husbandry in southeastern Brazil.

\section{Material and Methods}

\section{Study area and sampling}

The State of Minas Gerais is located in southeastern Brazil (Figure 1). It has an area of $588,383 \mathrm{~km}^{2}$, a mostly tropical climate and a mean annual temperature of $21.2{ }^{\circ} \mathrm{C}$. Annual rainfall varies from 1000 to $2000 \mathrm{~mm}$, with well-defined dry and wet seasons. To select the producers, nonprobabilistic sampling was used, from information sources obtained from the Agriculture and Livestock Institute of Minas Gerais (Instituto Mineiro de Agropecuária - IMA), Association of Sheep and Goat Producers of the State of Minas Gerais (Associação de Criadores de Caprinos e Ovinos do Estado de Minas Gerais - ACCOMIG) and the Technical Assistance and Rural Extension Company of Minas Gerais (Empresa de Assistência Técnica e Extensão Rural de Minas Gerais - EMATER/MG). Veterinarians within the Agriculture and Livestock Institute of Minas Gerais carried out blood sampling and applied the questionnaires. 
Figura 1. One hundred fifty-one municipalities with 284 goat properties sampled in the twelve mesoregions of Minas Gerais, southeastern Brazil.

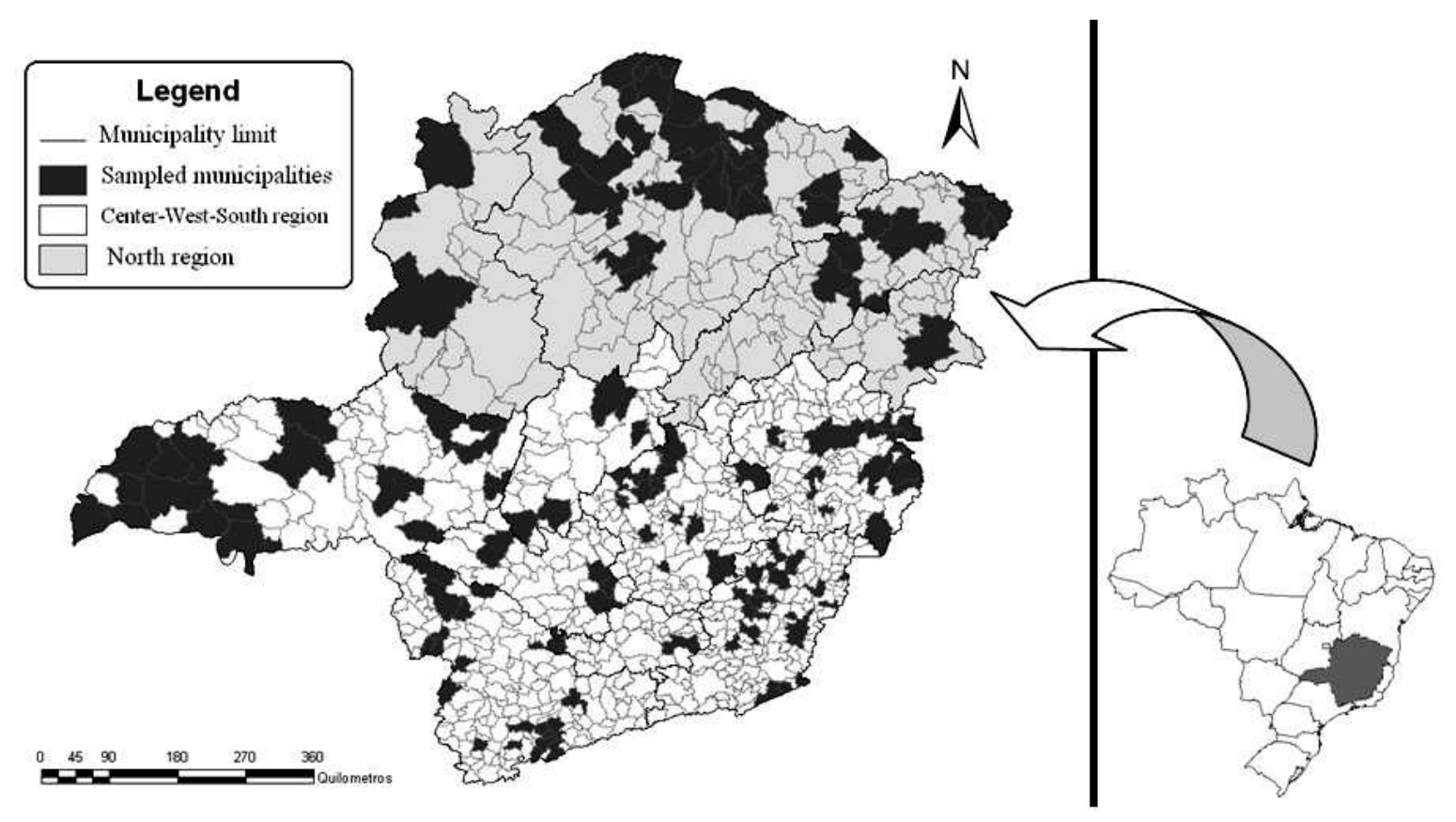

\section{Questionnaire to farmers}

The updated questionnaire, previously tested (MAGALHÃES et al., 1985; PINHEIRO et al., 2000), was filled out for each herd. It was applied directly to the individual responsible, focusing on problems occurring within a one year period and requesting data on the farm and herd. On the farms which had mixed husbandry (sheep and goats) data for both sheep and goats were obtained.

According to the type of rearing system, an extensive system was considered, in which animals were raised exclusively on pasture, eventually brought back at night for protection against predators, but without food supplementation in any period of the year. The semi-extensive system envolves some food supplementation, ration or forage, depending on dry or rainy season, and the confined system uses no grazing, keeping animals confined and receiving all of their nutritional requirements in the trough.

\section{Data analyses}

Based on 284 questionnaires, epidemiological and health profile of the sample was determined. A data bank was developed by using Windows Excel 98 and Epi Info (DEAN et al., 1995) software, establishing the frequency of each variable in the sample. Comparison of frequencies was performed by using Chi-square test.

\section{Results and Discussion}

The number of goats in herds sampled ranged between 2 and 308, with an average of 63 animals per property.

Table 1 shows the number of farms which employs various management measures at dairy and beef goat farms. The farming systems showed different features in MG. The predominantly confined production on dairy farms is explained by their small area, which is due to high land prices, higher than those in the north of the State where 
the extensive system of beef goat production is common (SEYFFERT et al., 2010). The confinement contributes to higher productivity and weight gain of the animals, but difficulties found in intensive livestock production are the high cost of labor, high feed prices, increasing animal density with increased risk of disease transmission and environmental stress on milk production, requiring the greatest health care (BORGES, 2003; GOUVEIA et al., 2009).

Table 1. Frequency distribution of 84 dairy goat and 200 beef goat farms in Minas Gerais, Brazil, concerning practice or management measures ( $\mathrm{n}=$ number of farms).

\begin{tabular}{|c|c|c|c|c|}
\hline \multirow{2}{*}{ Practice or management measures adopted } & \multicolumn{2}{|c|}{ Dairy goat herds } & \multicolumn{2}{|c|}{ Beef goat herds } \\
\hline & $\mathrm{n}^{\mathrm{a}}$ & $\%$ & $\mathrm{n}^{\mathrm{a}}$ & $\%$ \\
\hline Extensive farming & $0^{\text {a }}$ & 0.0 & $99^{\mathrm{b}}$ & 49.5 \\
\hline Semi-extensive farming & $1^{\mathrm{a}}$ & 1.2 & $98^{\mathrm{b}}$ & 49.0 \\
\hline Confined farming & $83^{\mathrm{a}}$ & 98.8 & $3^{b}$ & 1.5 \\
\hline Individual identification and herd records & $62^{\mathrm{a}}$ & 73.8 & $15^{\mathrm{b}}$ & 7.5 \\
\hline Use of quarantine for new animals & $13^{\mathrm{a}}$ & 15.5 & $8^{\mathrm{b}}$ & 4.0 \\
\hline Isolation of sick animals & $26^{\mathrm{a}}$ & 30.9 & $22^{b}$ & 11.0 \\
\hline Deworming in new animals & $40^{\mathrm{a}}$ & 47.6 & $53^{\mathrm{b}}$ & 26.5 \\
\hline $\begin{array}{l}\text { Requisition of sanitary certificate in the acquisition of new } \\
\text { animals }\end{array}$ & $24^{\mathrm{a}}$ & 28,6 & $3^{b}$ & 1,5 \\
\hline Presence of regular technical assistance & $44^{\mathrm{a}}$ & 52.4 & $66^{\mathrm{b}}$ & 33.0 \\
\hline Not informed & $14^{\mathrm{a}}$ & 16.7 & $101^{\mathrm{b}}$ & 50.5 \\
\hline
\end{tabular}

${ }^{a}$ Different letters between columns indicate significant differences $(P<0.05)$, dairy vs. beef.

Magalhães et al. (1985), in a survey conducted on dairy goat farms located at southeastern Brazil in the States of Rio de Janeiro and MG, found $54.2 \%$ of farms with goats in an confined and $45.8 \%$ in a semi-extensive system. At that time, imported animals and their offspring needed special care for adaptation to environmental and management conditions, and the percentage of farms with intensive systems was higher. Currently, animals are adapted to local conditions and can be raised in a less intensive system without compromising productivity. The production systems reflect farmers' current socioeconomic conditions.

Dairy goat production, with an average size of 63 goats per farm, showed higher levels of technology determined by the adoption of appropriate management practices and integrated control of parasites. According to Guimarães et al. (2011), 30\% (25/83) of dairy herds were classified as having high and $47.0 \%$ (39/83) were classified as having medium technological level, which demonstrates the good rate of use of good sanitary and management measures. Ninety-eight percent $(193 / 200)$ of beef goat farms presented medium or low technological levels.

Currently, the raising of dairy goats in $\mathrm{MG}$ is located mainly near Belo Horizonte region, South, Central, Forest Zone, Metallurgical Zone and Triângulo Mineiro (IBGE, 2013) located near to consumers markets and with higher level of technicization. Due to the high cost of production in those regions and the need to control gastrointestinal parasites, the confinement had been adopted in dairy systems, with specialized breeds of animals for milk production, as saanen, alpine and toggenburg breeds or crossbreeds (MAGALHÃES et al., 1985; BORGES, 2003; GUIMARÃES et al., 2011).

The small size of beef goat herds suggests family-based agriculture, where sheep and goat co-raising is practiced in extensive systems and 
presents higher mortality rates and lower levels of technological assistance (PINHEIRO et al., 2000). In the extensive/semi-extensive system, predominant for beef herds, the use of free-range pasture and ineffective control programs for mainly goat diseases, as well as the cohabitation of young and adult animals (data not shown) in the same area probably had an influence on many problems in goat husbandry. Currently, commercial beef goat husbandry has increased considerably in the state of $\mathrm{MG}$, with marketing in supermarkets and restaurants in major cities. The Brazilian population has surpassed old resistance to consumption of goat meat, with demand for meat from young animals and good quality, being exploited by medium and big farmers and an important source of income (SOUSA, 2007; SAMPAIO et al., 2009).

Goats must be identified in the first week of life, which is necessary for adequate monitoring of productivity and to make zootechnical records. This practice allows the selection of the more productive animals with monitoring of weight gain and milk productivity (YORINORI, 2001; GUIMARÃES, 2006; GUIMARÃES et al., 2011). Individual identification of animals had good frequency of use in dairy goat farms, which reflects its importance. Similar indexe were found by Magalhães et al. (1985), in State of MG, in which $75 \%$ of dairy goat farmers have identified the sampled animals. Unlike dairy goat farmers, beef goat farmers wrongly tend not to identify the animals on the basis of the commercial goal of the activity, since these animals will soon be slaughtered.

The use of isolation areas for sick and quarantined to keep the newly acquired or sick animals' aparted from the herd is an important practice in order to prevent the introduction of important diseases and helminth infections, and the likelihood of acquiring resistant parasites would increase proportionately to the amount of newly introduced animals (COLES; ROUSH, 1992). The intensive interregional and interstate transit of goats facilitates the exchange of pathogens and parasites from distant flocks (GUIMARÃES et al., 2009) and we think that this situation is aggravated by the limited use of quarantine in the dairy and beef flocks. These practices were mostly used in the dairy goat farms (data not shown), characterized by confined and semi-extensive farming systems. Caldas (1989), in a study on the goat husbandry at 2096 farms in the northeastern State of Bahia, reported that there are many health problems and that infectious and parasitic diseases constitute a serious obstacle to the development of the farms, representing considerable livestock losses with great economic impact. Similarly, Pinheiro et al. (2000), in the State of Ceará, regarding goat herds for subsistence, reported little use of such sanitary practices, suggesting that the frequency of use varies according to the system.

Few farmers required a sanitary certificate in the acquisition of new animals. The sale of dairy goats from MG to States of the Northeast of Brazil and the purchase of beef goats from this region to $\mathrm{MG}$ are frequent (ARCO, 2011) and the lack of sanitary documentation may allow the dissemination of important infectious agents. Among the farmers who require sanitary certificates, some of them required them for caprine arthritis encephalitis, brucellosis and tuberculosis, these last two diseases, mistakenly, required for transit of cattle. The low demand for sanitary certificates can be explained by the low level of knowledge regarding the diseases in goat herds and and their losses in productivity. Moreover, technical assistance to the sampled farms is limited, as well as access to diagnostic laboratories. Also, when the diagnosis is taken, most of the specific vaccines are not found in the market, and the availability of commercial products for diagnosis, treatment and prevention of sheepspecific diseases is equally limited (GUIMARÃES et al., 2009).

Fifty percent (42/84) of dairy goat breeders and $53.0 \%$ of beef goat breeders used some type of vaccine. Among the 84 dairy goat breeders, 4 (48.0\%) used vaccine against clostridiosis, 1.2\% 
(1/84) against caseous lymphadenitis, $23.8 \%(20 / 84)$ against rabies and 20.2\% (17/84) against foot and mouth disease. Among the 200 beef goat breeders, $12(6,0 \%)$ used vaccines against clostridiosis, $20 \%$ (40/200) against rabies, 27\% (54/200) against foot and mouth disease and no one used vaccines against caseous lymphadenitis.

It is important to note that $50 \%$ of goat breeders vaccinated the herds against some kind of disease, but most of them vaccinated them against foot and mouth disease unnecessarily according to Brazilian laws (MAPA, 1993, 1995). Domestic species of cloven hoofed animals are subject to contract foot and mouth disease. By order of susceptibility such animals are pigs, cattle, buffaloes and small ruminants, in fact, pigs are the infection sentinels, not the small ruminants. They are mistakenly vaccinated because some breeders think that the small ruminants are sentinels of the infection in cattle. This situation reflects the unfamiliarity with the main ways to control diseases which can bring serious economic harm to the goat husbandry. Clostridial and rabies vaccines are cited by herd managers. Vaccination against rabies and clostridials are common and deserve special attention because the damage they can cause in herds. Vaccination against caseous lymphadenitis was cited by only one dairy farmer although the great economic importance. Seyffert et al. (2010) found a prevalence of $78.9 \%$ and $98.00 \%$ of positive herds for caseous lymphadenitis in MG State, thus, it is possible to infer that the bacteria is disseminated in this goat population and is overlooked by most farmers.

Table 2 shows the major pathological disorders reported by owners in 84 dairy and 200 beef goat herds in 151 municipalities of the State of Minas Gerais.

Table 2. Frequency distribution of 84 dairy goat and 200 beef goat farms in Minas Gerais, Brazil, concerning major pathological disorders cited as present in goat herd $(n=$ number of farms).

\begin{tabular}{lcccc}
\hline \multirow{2}{*}{ Variable } & \multicolumn{2}{c}{ Dairy goats } & \multicolumn{2}{c}{ Beef goats } \\
\cline { 2 - 5 } & $\mathrm{n}^{\mathrm{a}}$ & $\%$ & $\mathrm{n}^{\mathrm{a}}$ & $\%$ \\
\hline Abortion & $42^{\mathrm{a}}$ & 50.0 & $99^{\mathrm{a}}$ & 49.5 \\
Mastits & $35^{\mathrm{a}}$ & 41.7 & $38^{\mathrm{b}}$ & 19.0 \\
Pneumonia & $23^{\mathrm{a}}$ & 37.4 & $33^{\mathrm{b}}$ & 16.5 \\
Diarrhea & $29^{\mathrm{a}}$ & 34.5 & $55^{\mathrm{a}}$ & 27.7 \\
Arthritis & $20^{\mathrm{a}}$ & 23.8 & $20^{\mathrm{b}}$ & 10.0 \\
Caseous lymphadenitis & $17^{\mathrm{a}}$ & 20.2 & $86^{\mathrm{b}}$ & 43.0 \\
Keratoconjunctivitis & $14^{\mathrm{a}}$ & 16.7 & $29^{\mathrm{a}}$ & 14.5 \\
Pododermatitis & $12^{\mathrm{a}}$ & 14.3 & $24^{\mathrm{a}}$ & 12.0 \\
Nervous symptoms & $8^{\mathrm{a}}$ & 9.5 & $7^{\mathrm{b}}$ & 3.5 \\
Contagious ecthyma & $5^{\mathrm{a}}$ & 5.9 & $44^{\mathrm{b}}$ & 22.0 \\
Not informed & $2^{\mathrm{a}}$ & 2.4 & $28^{\mathrm{b}}$ & 14.0 \\
\hline
\end{tabular}

${ }^{a}$ Different letters between columns indicate significant differences $(P<0.05)$, dairy vs. beef.

Technical monitoring of the herd by veterinarians, zootechnicians or agronomists was considered. Technical assistance is an important factor for the growth of the goat husbandry, i.e., for the adoption of good sanitary practices, such as monitoring of programs for prevention and control of diseases and good nutritional management (GUIMARÃES et al., 2009; SILVA et al., 2011). In MG, the highest level of technical assistance was detected in dairy farms, because of commercial dairy farming is more traditional in the state, compared to beef farming (GUIMARÃES et al., 2009). Much of the herds 
were assisted by veterinarians, who can facilitate recognition, diagnosis and prevention of infectious diseases. In general, the sanitary practices found at dairy goat farms contribute to the maintenance of a better technological level compared to beef goat farms. In farming, dairy and beef, the results indicate the need for training of technicians, for proper sanitary management because these professionals are essential to monitor the prevention and control programs in herds (GUIMARÃES et al., 2009; SILVA et al., 2011).

\section{Conclusions}

The restricted use of quarantine, no isolation of sick animals, no separation of animals by age group and little use of technical assistance on the farms sampled can be considered the main responsible factors for the spread of diseases inside the herds, such as abortion, diarrhea, pneumonia keratoconjunctivitis, caseous lymphadenitis and contagious ecthyma.

Dairy goat properties in Minas Gerais have good sanitary and management practices. Even so, some practices needs better technical support, such as vaccination and laboratory diagnosis for major diseases of dairy goats, as a way to increase productivity and quality of the milk produced.

The main challenges for the goat chain in MG are the constant supply of quality products, increased livestock productivity, with reduced production costs and increased profitability, as an alternative to generating employment and income for farmers.

\section{Acknowledgements}

We thank the Agriculture and Livestock Institute of Minas Gerais (Instituto Mineiro de Agropecuária - IMA) and their veterinarians for their help during the course of this project, collecting sera and filling out questionnaires on goat herds in Minas Gerais; Conselho Nacional de Desenvolvimento Científico e Tecnológico (CNPq), Coordenação de Aperfeiçoamento de Pessoal de Nível Superior (CAPES) and Fundação de Amparo a Pesquisa do Estado de Minas Gerais (Fapemig).

\section{References}

ARQUIVO DA ASSOCIAÇÃO BRASILEIRA DE CRIADORES DE OVINOS. Comunicados técnicos. Bagé: ARCO, 2011. Disponível em: <http://www. arcoovinos.com.br>. Acesso em: 09 abr. 2013.

BORGES, C. H. P. Custos de produção do leite de cabra na região Sudeste do Brasil. In: SIMPÓSIO INTERNACIONAL SOBRE CAPRINOS E OVINOS DE CORTE I SIMPÓSIO INTERNACIONAL SOBRE O AGRONEGÓCIO DA CAPRINOCULTURA LEITEIRA, 2., 2003, João Pessoa. Anais... João Pessoa, 2003. p. 1-14.

CALDAS, E. M. Estudo da ovinocaprinocultura na região nordeste do estado da Bahia. Arquivo Escola de Medicina Veterinária da Universidade Federal da Bahia, Salvador, v. 12, p. 1-98, 1989.

COLES, G. C.; ROUSH, R. T. Slowing the spread of anthelmintic-resistant nematodes of sheep and goats in the United Kingdom. Veterinary Record, Liverpool, v. 130, n. 23, p. 505-510, 1992.

DEAN, A. G.; DEAN, J. A.; BURTON, A. H.; DICKER, R. C. EPIINFO, a word processing, date base and statistis program for epidemiology on microcomputers. Version 6. 02. Georgia: USD, 1995. 599 p.

FONSECA, J. F.; BRUSCHI, J. H. A caprinocultura leiteira no Brasils: uma visão histórica. Belo Horizonte: Caprileite, 2009. Disponível em: <http://www. caprileite.com.br/conteudo.php?id_conteudo $=172 \& \mathrm{id}$ links $=4 \& i d \_s u b \_l i n k s=26>$. Acesso em: 03 out. 2013.

GOUVEIA, A. M. G.; GUIMARÃES, A. S.; HADDAD, J. P. A. ABREU, C. P., CRUZ, J. C. M., CARMO, F. B. Características zoosanitárias da caprinocultura leiteira em Minas Gerais, Brasil. Belo Horizonte: Caprileite/ACCOMIG, 2009. Disponível em: $<$ http://www.caprileite.com.br/arquivos/ sdaCaprinoculturadeLeite10MG07032013_103411. pdf $>$. Acesso em: 03 out. 2013. 
GUIMARÃES, A. S. Caracterização da caprinovinocultura em Minas Gerais. 2006. Dissertação (Mestrado em Medicina Veterinária Preventiva) - Escola de Veterinária da Universidade Federal de Minas Gerais, Belo Horizonte.

GUIMARÃES, A. S.; GOUVEIA, A. M. G.; CARMO, F. B.; GOUVEIA, G. C.; SILVA, M. X.; VIEIRA, L. S.; MOLENTO, M. B. Management practices to control gastrointestinal parasites in dairy and beef goats in Minas Gerais; Brazil. Veterinary Parasitology, Amsterdam, v. 176, p. 265-269, 2011.

GUIMARÃES, A. S.; SEYFFERT, N.; BASTOS, B. L.; PORTELA, R. W. D.; MEYER, R.; CARMO, F. B.; CRUZ, J. C. M.; MCCUlLOCH, J. A.; LAGE, A. P.; HEINEMANN, M. B.; MIYOSHI, A.; AZEVEDO, V.; GOUVEIA, A. M. G. Caseous lymphadenitis in sheep of the State of Minas Gerais, Brazil: prevalence and management surveys. Small Ruminant Research, v. 87, n. 1-3, p. 86-91, 2009.

INSTITUTO BRASILEIRO DE GEOGRAFIA E ESTATÍSTICA - Banco de dados agregados. Brasília: IBGE, 2013. Disponível em: <http://www.ibge.gov.br/ home/estatistica/economia/ppm/2010/tabelas_pdf/tab16. pdf $>$. Acesso em: 31 nov. 2013.

MAGALHÃES, H. H.; GOUVEIA A. M. G.; CAPISTRANO, C. M. B. Diagnóstico da situação da caprinocultura em algumas microrregiões dos Estados de Minas Gerais e Rio de Janeiro. Revista Cabras \& Bodes, Belo Horizonte, v. 1, p. 5-7, 1985.

MINISTÉRIO DA AGRICULTURA, PECUÁRIA E ABASTECIMENTO - MAPA. Secretaria de Defesa Agropecuária, Portaria $n^{\circ}$ 121, 29 mar. 1993. Brasília, 1993.

Secretaria de Defesa Agropecuária, Portaria $n^{\circ}$ 713, 1 nov. 1995. Brasília, 1995.

PINHEIRO, R. R.; GOUVEIA, A. M. G.; ALVES, F. S. F.; HADDAD, J. P. A. Aspectos epidemiológicos da caprinocultura cearense. Arquivo Brasileiro Medicina Veterinária Zootecnia, Belo Horizonte, v. 52, n. 5, p. 534-543, 2000.

SAMPAIO, B. R.; SAMPAIO, Y.; LIMA, R. C. AIRES, A.; SAMPAIO, G. A economia da caprinocultura em Pernambuco: problemas e perspectivas. Revista Economia, Brasília, v. 35, n. 22, p. 137-159, 2009.
SEYFFERT, N.; GUIMARÃES, A. S.; PACHECO, L. G. C.; PORTELA, R. W.; BASTOS, B. L.; DORELLA, F. A.; HEINEMANN, M. B.; LAGE, A. P.; GOUVEIA, A. M. G.; MEYER, R.; MIYOSHI, A.; AZEVEDO, V. High seroprevalence of caseous lymphadenitis in Brazilian goat herds revealed by Corynebacterium pseudotuberculosis secreted proteins-based ELISA. Research Veterinary Science, v. 88, n. 1, p. 50-55, 2010.

SILVA, R. A. B.; BATISTA, M. C. S.; NASCIMENTO, C. B.; ALVES, R. P. A.; ALVES, F. S. F.; PINHEIRO, R. R.; SOUSA, M. S.; DINIZ, B. L. M.; CARDOSO, J. F. S.; PAULA, N. R. O. Caracterização zoosanitária da ovinocultura e da caprinocultura na microrregião homogênea de Teresina, Piauí, Brasil. Arquivos do Instituto Biológico, São Paulo, v. 78, n. 4, p. 593-598, 2011.

SOUSA, W. H. O agronegócio da caprinocultura de corte no Brasil. Tecnologia \& Ciência Agropecuaria, João Pessoa, v. 1, n. 1, p. 51-58, set. 2007.

SOUZA NETO, J., BAKER, G. A., SOUSA, F. B. Caprinocultura de duplo propósito no Nordeste do Brasil: avaliação do potencial produtivo. Relatório Técnico do Centro Nacional de Pesquisa de Caprinos 1987-1995. Sobral: Embrapa Caprinos, 1996. p. 210-212.

SOUZA NETO, J.; BAKER, G. A.; SOUSA, F. B. Caprinocultura de duplo propósito no Nordeste do Brasil: avaliação do potencial produtivo. Editora Embrapa Caprinos, Sobral, Ceará, 1996. p. 210-212. (Relatório técnico).

SOUZA NETO, J.; GUTIERREZ, N. Características gerais da caprinocultura leiteira no Estado da Paraíba. Sobral: Boletim de Pesquisa, Embrapa Caprinos, 1987. $28 \mathrm{p}$.

TINÔCO, A. L. A. Diagnóstico de situação da ovino/ caprinocultura em três municípios do sertão baiano Euclides da Cunha, Quijingue, Monte Santo - Bahia, 1981/1982. 1983. Seminário (Especialização Medicina Veterinária Preventiva) - Escola de Veterinária da Universidade Federal de Minas Gerais, Belo Horizonte.

YORINORI, E. H. Características dos sistemas de produção de pequenos ruminantes e prevalência da artrite encefalite caprina (CAE) e Maedi-Visna( MV) ovina, nas regiões norte e nordeste de Minas Gerais. 2001. Dissertação (Mestrado em Medicina Veterinária Preventiva) - Escola de Veterinária da Universidade Federal de Minas Gerais, Belo Horizonte. 